\title{
MONASTIC REFORM AND AUTOBIOGRAPHICAL DIALOGUE: THE SENATORIUM OF ABBOT MARTIN OF LEIBITZ
}

\author{
Harald Tersch \\ Universität Wien \\ harald.tersch@univie.ac.at \\ orcid.org/o0oo-0003-1800-8679
}

Recepción: 08-OI-20I6 / Aceptación: 22-II-20I6

\begin{abstract}
The autobiographical dialogue is based upon the principle of questioning the fundamentals of one's own life script and offered itself in particular during times of reform movements, when role models and values within communities were open to debate. The monastic reforms of the $14{ }^{\text {th }}$ and $15^{\text {th }}$ centuries created a new authority with the category of Visitors who frequently did not advance according to the hierarchy of the monastery visited, but instead entered them laterally, in order to ensure the long-term success of the arrangements. This authority to exert power increased the need for justification. In his Senatorium the Benedictine reform abbot and Visitor Martin of Leibitz/L'ubica (I400-I464) legitimized his self-reflection with the claim to a didactic conversation in the tradition of the Gregorian Dialogues, the Bohemian Malogranatum and the Formicarius of Johannes Nider. The dialogue relates the conversation between a youth and an old man. The elderly man (senex) is Martin's "alter ego" who wishes to speak of his experience according to the classical stages of life, the young man represents an inquisitive cue-giver who challenges his partner by agreement or contradiction. The autobiography suggests the atmosphere of a chapter hall. It is drawn on the modus of an inquisitio and filled with contemporary possibilities for monastic self-thematization in interviews, visitiation reports or letters. In contrast to Petrarch's Secretum, the Senatorium does not have the character of a private examen conscientiae, because Martin publicly acknowledges transgressions against the rules and their local adaptions, as with the peccata hominis exterioris, which should be laid bare communally.
\end{abstract}




\section{Keywords}

Autobiography, Dialogue, Benedictine reform, Cusanian visitation, Monastic historiography.

\section{Resumen}

El diálogo autobiográfico se basa en el principio de cuestionar los fundamentos del propio guión de la vida y, partitcularmente, se desarrolló en durante en las épocas de los movimientos de reforma, cuando los modelos y los valores dentro de las comunidades estaban abiertos al debate. Las reformas monásticas de los siglos XIV y XV crearon una nueva autoridad con la categoría de 'visitantes' que con frecuencia no avanzaba en consonancia con la jerarquía del monasterio visitado, sino paralelamente, para garantizar el éxito a largo plazo de los cambios. Esta autoridad para ejercer poder aumentó la necesidad de justificación. En su Senatorium, el abad de la reforma benedictina y el visitador Martín de Leibitz / L'ubica (I400-I464) legitimaron su autorreflexión con la llamada de una conversación didáctica en la tradición de los Diálogos gregorianos, el bohemio Malogranatum y el Formicarius de Johannes Nider. El diálogo relata la conversación entre un joven y un anciano. El hombre mayor (senex) es el "alter ego" de Martin que desea hablar de su experiencia de acuerdo con las etapas clásicas de la vida, el joven representa un hombre inquisitivo que asiente o disiente. La autobiografía sugiere la atmósfera de una sala capitular. Se basa en el modo de inquisitio y se llena de posibilidades coetáneas para la tematización monástica en entrevistas, informes de visita o cartas. A diferencia del Secretum de Petrarca, el Senatorium no tiene el carácter de un examen conscientiae privado, porque Martin reconoce públicamente las transgresiones contra las reglas y sus adaptaciones locales, como con los peccata hominis exterioris, que debe revelarse ante la comunidad.

\section{Palabras clave}

Autobiografía, Diálogo, Reforma benedictina, 'Visita cusana', Historiografía monástica.

\section{THE AUTOBIOGRAPHICAL DIALOGUE}

Late Medieval writing culture reveals itself to be eager to experiment in the area of self-expression. In the emergent vernacular tradition, visionary literature, love poetry or domestic conduct books could serve as conduits for individualized life stories. In the Latin academic culture, moreover, the genre of the dialogue 
expanded the existing possibilities of self-representation and self-reflection. In comparison with the closed narrative retrospective of a Vita, the autobiographical dialogue was based upon the principle of questioning, confirming or rejecting the fundamentals of one's own life script by means of a counterpart in the form of a conversation partner. The fictive form offered itself in particular during times of social reform movements, when ways of living and values within communities were open to debate. Petrarch's Secretum (ca. 1350) represents a key text in medieval studies; in this work, Francis as "figura auctoris" converses with his discussion partner Augustine regarding the conduct of his life and his moral condition. The figures represent two different meta-positions, which allow the autobiographer to confront controversial opinions about himself and to scrutinise social role models. The Secretum is based on differing genre traditions. It stands primarily in the line of succession of the Augustinian Confessions and Soliloquies, "in which a person and his rational spirit entered into debate in the interior of the soul on the preconditions and limitations of self-knowledge". An additional model for Petrarch was provided by The Consolation of Philosophy of Boethius, whose dialogue with "Lady Philosophy" could be understood as self-representation. An investigation into autobiographical prison writing of the $14^{\text {th }}$ and $15^{\text {th }}$ century has revealed that authors frequently stylised themselves as Boethian figures. ${ }^{3}$ In pseudo-Boethian conversations, abstract female personifications did not always confront the authors, but sometimes figures of authority, appropriate to the autobiographical situation, were invoked. The English poet-counselor Thomas Hoccleve, for example, in the opening dialogue of his poem Regement of Princes (I4IOII) replaced consolatory philosophy with an unnamed Old Man. ${ }^{4}$ Besides the tradition of Soliloquia and Consolatio, in the late Middle Ages additional points of contact for the development of autobiographical dialogue offered themselves. The following remarks about a Benedictine example from the mid-I $5^{\text {th }}$ century are intended to draw attention to the monastic tradition following Gregory the Great whose Dialogi between Gregory and the deacon Peter begin with a firstperson narrative and equally were read literally as autobiographical document.

The consideration of the autobiographical dialogue alone from the perspective of classical early Christian prototypes is not suitable for the literary phenomeon. Interpretative approaches, which work out the intertextuality of the dialogue

\footnotetext{
I More current examples, see Hermans / Hermans-Konopka, 20IO, p. I5I.

2 Stock, 200I, pp. II, I7; also McLaughlin, 2004, p. 56; Lee, 20I2, p. 78.

3 Summers, 2004, p. I2-I8.

${ }^{4}$ See Knapp, 2009, p. 197.
} 
with contemporary functional texts, are worthy of attention. The innovative thesis, according to which the Secretum is connected directly or indirectly to $13^{\text {th }}$ and I4 ${ }^{\text {th }}$ century confessional practice, led in this direction. Vernacular handbooks of penance, with their interrogatory, accordingly defined a dialogue situation in which Augustine as confessor directed the self-awareness of the penitent Francis. ${ }^{5}$ Procedural manuals which determined judicial or inquisitorial interrogations were equally influential for late Medieval and early Modern autobiography. They represent an important link between voluntary and forced "ego-documents", which can overlap each other in the conditions of their composition and formation. ${ }^{6}$ In the autobiographical prison writing of the late Middle Ages the dialogue found an entry not only through references to Boethius but also through the dramatics of the conversation between the interrogator and the accused author. Trials for heresy and Visitations made the interview in the late Middle Ages into a significant technique of self-stylisation, which confronted the official perspective of acts and protocols with the personal authority of the narrator. ${ }^{7}$ In his autobiographical dialogue, Senatorium, the Benedictine monk Martin of Leibitz (or "of Vienna") drew on the modus of an inquisitio.

\section{MONASTIC REFORM AND AUTOBIOGRAPHY}

The autobiography of the high Middle Ages moved in the realm of biography and Gesta. The authors originated predominantly from the monastic environment and followed, like Augustine, the concept of an imitatio of pious paragons, which they discovered according to the Regula Benedicti in the conversion stories contained in the lives of saints. Although the monastic autobiography of the late Middle Ages indeed oriented itself on the same patterns of behaviour, nevertheless the scribal class had altered. In the $12{ }^{\text {th }}$ century it was primarily the powerful abbots and prelates of aristocratic background who conveyed the tense relationship between leadership, contemplation and temptation in their respective environments. The monastic reforms of the $14^{\text {th }}$ and $15^{\text {th }}$ centuries created a new authority with the category of academically trained Visitors. Visitors travelled on papal and ducal orders to monasteries, swore them to programmes of reform, imposed limits on the

\footnotetext{
5 See Zimmermann, 1971, pp. I24-I34.

${ }^{6}$ See Amelung, 20II, pp. 33-40.

7 See Summers, 2004, pp. I08-II9.

${ }^{8}$ See Fleming, 20I4, pp. 36-39; Rubinstein, 2005, pp. 25-26.
} 
influence of officials, and when necessary deposed abbots. They frequently did not advance according to the hierarchy of the monastery visited, but instead entered them laterally, in order to ensure the long-term success of the reforms. This unfamiliar authority to exert power increased the need for justification, which expressed itself in the form of personal testimonials. The Visitors thereby seized on their own inquisitorial means, with which they controlled the monastic way of life.

The Visitor Martin of Leibitz (or "of Vienna") was born in ca. I400 in the Upper Hungarian region Zips (Slovakian Spiš), where he grew up in Leibitz (Slovakian L'ubica). After attending the Latin schools in Krakow and Neisse (Polish Nysa) in I420 he came to the University of Vienna, where he became master of arts, and subsequently completed a study in canon law. ${ }^{9}$ According to his own statements, he had to study as a lodger of a noble master, upon whom he was so dependent that should he leave his position there, he feared repercussions against his own relatives. ${ }^{\text {IO }}$ During a pilgrimage to Rome, he visited the reformed Benedictine monastery Sacro Speco (Subiaco), where he became a monk in I43I. The so-called "Melk Reform", named after Melk Abbey, embraced by Austria and southern Germany and built upon the consuetudines Sublacenses, emanated from Sacro Speco. II Regular gatherings and visitations were intended to oblige the monasteries of the congregation to adhere to those ideals which were recorded in the Regula Benedicti. After returning to Vienna, Martin entered the Benedictine Scottish Abbey, which had already been reformed in I4I8. There he was first prior, then in 1446 abbot, and obtained from the Holy See the complete exemption for his monastery. In the years I45I/I452 he led the visitation, prescribed by the papal legate Cardinal Nicolaus Cusanus, to the monasteries in the Archdiocese of Salzburg. Martin of Leibitz was one of the regents for the under-age Habsburg ruler Ladislaus V. Postumus, and he participated in Austrian government affairs until the latter's death in I457. In late I460 or early I46I, the abbot relinquished his office and dedicated himself primarily to his writing. The opening sermon for the Cusanian Visitation of I45I/I452, as well as a number of didactic-edifying dialogues, count amongst his most important works. In the period from his resignation to his death in 1464 he also composed the dialogue Senatorium, which relates the conversation between a youth (juvenis) and an old man (senex). The aged man wishes to speak of his experience (experientia), since

9 See Siegmund, 1980, col. 683-684; Frank/Worstbrock, 1987, col. I53-I54; Achitz, 2012-2013, vol. 2, col. 777-778.

10 Pez, I725, col. 634-635.

II See Niederkorn 1994, pp. I7-I8. 
forgetfulness is the mother of ingratitude, and therefore follows the chronology of his life. Behind the elderly man is Martin himself, so that the title also points to the autobiographical content of the work: "SENATORIUM a Sene" or "DIALOGUS cujusdam Senis" (Pez, I725, col. 625, 673).

The introduction of an autobiographical "I", in the monastic literature of the late Middle Ages, was charged with the stigma of vanity. At the same time as the Senatorium, the Itinerarium of Wolfgang of Steyr (de Stira, I4O2-I498) was written; he had participated in the visitation of his home abbey Melk, and became prior there in I463. In his Itinerarium on the occasion of his entering the monastery in I425, he presents himself self-confidently: "indui EGO FRATER WOLF DE STYRA habitum Novitiorum sub Abbate Nicolao, Priore vero Johanne de Werdea, in 23. anno aetatis meae" (Pez, 1725, col. 447). The writer here associates his conversion with the charismatic personality of Nikolaus Seyringer (ca. 1360-I425), who as abbot first of Subiaco and then of Melk had made efforts to disseminate the reforms. Since the Itinerarium largely contains contemporary reports since the time of the Council of Constance, the "ego" endows the author with a certain "historiographical" authority, which qualifies him as a coeval witness of the visitations and reforms. The use of the first person was to be avoided when the personal accomplishments constituted the central theme of the text, and the act of writing thereby entered into conflict with the Christian virtue of humility. Martin of Leibitz enjoyed an active written correspondence with the predecessor of Wolfgang, the Melk prior Johannes Schlitpacher (de Weilheim, I403-I482). Schlitpacher was equally an influential participant in the Cusanian Visitation of $145 \mathrm{I} / 52$, and was engaged in an extensive literary œuvre for monastic reform. In addition to Latin commentaries, treatises and carmina, these included a survey of famous members of the Benedictine order, taking up the tradition of the monastic lives of saints. A Vita is preserved in Tegernsee Abbey in Bavaria which describes the life of Schlitpacher, sketches the formation of his critical commentary on the Regula Benedicti, and contains a comprehensive index of his works. The biography illustrates less the monk than the humanistic teacher. Under the influence of Melk, Tegernsee developed into a new centre for reform, where Schlitpacher's writings and letters were eagerly collected, copied, and disseminated. The manuscript of the Vita names two Tegernsee monks as authors and includes at the end a letter of Schlitpacher dated to 1478; this has been pasted over, but it is still legible when held against the light. ${ }^{\mathrm{I} 2}$ In this letter, the prior of

I2 See Redlich, I93I, p. 216 
Melk expresses his wish to live on in memory after his death, and to this end he bids two Tegernsee friends to copy down the Vita and then to destroy his autograph. This indeed occurred, yet with the letter, the key to the autobiographical nature of the text was preserved. The prior even wrote the notification of his own death in the third person, so that the copyists only needed later to write in the year. Martin of Leibitz deflected any charge of being motivated by seeking a posthumous reputation, with the claim to a didactic conversation, which was intended to be edifying (aedificatorius) and useful (fructuosus). The figure of the elderly man enabled him to speak throughout in the first person.

With the "alter ego" of the elderly man, the author elevates his life story to a general, exemplary level, turning the experience into instruction for the next generation. The Senatorium leaves the spatial setting of the dialogue in obscurity for a long time, since the atmosphere of the Vienna Scottish Abbey only acquires its outline with the biographical development of the elderly man. At the beginning of the fourth chapter the youth requests the older man to tell about the Cusanian Visitation of $\mathrm{I} 45 \mathrm{I} / 52$ "pro informatione successorum", whereby he allows himself to be recognised as a young confrère, perhaps also as a lay brother, in any event as an interested student. The audience for the text is also to be sought in this social circle, and its appeal is attested by two manuscripts preserved in the monastic libraries of Melk (Cod. 139) and of Saint Peter in Salzburg (Cod. a. VI. 46). The active exchange of manuscripts amongst the reform monasteries functioned in this manner as a multiplier of reception within an ambit which could recognise the autobiographical content. In light of the scant transmission, the possibility exists that Martin withheld the manuscript during his lifetime, yet due to the statements in the prologue this remains uncertain. Besides the original manuscript in the Scottish Abbey in Vienna, individual copies also certainly were lost, such as a manuscript from the Carthusian monastery of Gaming (Lower Austria) dating to ca. I480, which was still mentioned at the beginning of the $18^{\text {th }}$ century. ${ }^{\mathrm{I}}$ Quotations from the Senatorium regarding the Cusanian Visitation appeared in 1702, published in the Chronicon Mellicense by the Benedictine historian Anselm Schramb, whereupon the Melk scholar Hieronymus Pez edited the text in 1725 on the basis of the Melk manuscript. This manuscript, however, is incomplete, so that the Salzburg manuscript represents an indispensable supplement for the understanding of the text. For example, the passages concerning the Pope Joan, passages which were later erased in Melk, can today only be completed from the

${ }^{13}$ See Wallnig, 20I0-20I5, vol. 2,I, p. 680. 
Salzburg manuscript. In the scholarship the "memoirs" of the Abbot served above all as a source for the progress of the Cusanian Visitation, and also as a mine of information regarding specific topics and motifs such as the female student disguised as a man, about whom Martin heard in Kracow. ${ }^{\text {I4 }}$ In studies of the Medieval dialogue, in contrast, the Senatorium played no role.

\section{THE SENTATORIUM AND THE DIALOGUE TRADITION}

The increasing number of autobiographies in the period around 1500 is based on a chain reaction, "in which certain texts awoke or restructured perceptions of the self, while these perceptions in turn created a demand for texts of this kind" (Burke, 1997, p. 27). The distinct integration into a long tradition of the genre allowed Martin of Leibnitz to delineate his work in the prologue of these existing models. Initially it was the dialogue partners whom he denoted as his invention, for although there were already conversations between Gregory and Peter, teacher and disciple, father and son, nonetheless "nusquam memor sum me repperisse Dialogum, ubi Senex loquitur cum Juvene” (Pez, I725, col. 625). The idea apparently pleased him so well that he used this combination of figures again in another dialogue by the name of Quotlibetarium, which addressed theological questions. ${ }^{15}$ The author finds a justification for the writing down of the Senatorium only in the singularity of his personal experience: "quae non puto alibi esse clare scripta". The desire to align with the tradition of dialogue, in order thereby to make something new of it, is reminiscent of Petrarch's recourse to Plato, Seneca and Cicero in his Latin dialogues Secretum and De remediis utriusque fortunae (1366). The moral-philosophical works of Petrarch were not unknown in the circle of the Melk Reform, since the close contact with the Italian "mother abbey" of Subiaco was not broken off. A German translation of Petrarch's Seniles XI,II is the work of Martin's companion Wolfgang of Steyr. ${ }^{16}$ In the Scottish Abbey, Vienna, there are a number of manuscripts preserved from the I450s and I460s with works of Petrarch, including also the Secretum. The therapeutic analysis of the soul, in such works as the autobiographical Secretum or the Augustinian Soliloquia, remains entirely foreign to the Senatorium.

${ }^{14}$ See Mixson, 2009, p. I47; Shank, 1987, p. 373-380.

${ }^{\text {I5 }}$ See Jellouschek, 1932, p. LIX, I85-I99.

${ }^{16}$ See Achitz, 20I2-2013, vol. 3, col. 698; Martin, I992, pp. 63-64. 
Martin of Leibitz measures his work against the monastic tradition in general and against the didactic dialogue in particular. With the conversation partners Gregory and Peter, in the prologue he mentions the Dialogi de vita et miraculis patrum Italicorum of Gregory the Great. Book IV of the Dialogi was considered to be a reference work for autobiographical narratives of visions, so that the Benedictine Otloh of Saint Emmeram (ca. IOIO-ca. I070) in his Liber visionum, in addition to the Bible, invokes only Gregory the Great as model. ${ }^{17}$ For centuries the Dialogi set the standard for monastic dialogues, as they combined didactic instruction with an exemplary biography, the life of St. Benedict (Book II). In works of the high and late Middle Ages, the biographical or the didactic aspect respectively could come to the fore, when it was necessary to discuss the moral conduct of an abbot or to communicate doctrine. ${ }^{\mathrm{I}}$ The Malogranatum, for example, belongs to the category of monastic instructional dialogues, to whose conversation partners, a father and son, Martin alluded in his prologue. In the work of a Bohemian Cistercian Abbey from the $14^{\text {th }}$ century, a Pater explains to his Filius the path to spiritual perfection before the young man enters the monastery. Martin frequently cites the Formicarius as the most significant prototype. This was a dialogue created in $1437 / 38$, which described in five books the ant colony as a model of human society. The dialogue, furthermore, draws on the book about bees, Bonum universale de proprietatibus apum, by Thomas of Cantimpré (I2OII270). The Formicarius was written by the Upper Swabian Dominican, Johannes Nider (d. I438), who studied in Vienna at the same time as Martin of Leibitz, so that they might well have known each other personally. ${ }^{19}$ Both men shared an active engagement with the reformation of their orders, which Nider promoted as vicar general of all Dominican reform monasteries of the province of Teutonia. The historical influence of his Formicarius was concentrated primarily on the observations concerning demonology, which found a wide reception in and with the notorious Malleus Maleficarum (I486) by his confrère, Henricus Institoris.

In the Formicarius, the Theologus instructs a Piger (a lazy individual) regarding good revelations and false visions, saints and theurgists. The person of the Piger embodies that lethargy in belief which Nider, by means of a series of examples and moral-theological arguments, intends to combat. ${ }^{20}$ The unequal relationship of the two dialogue partners corresponds to the configuration of Magister/Disci-

${ }^{17}$ See Schmitt, I998, p. 45 .

${ }^{18}$ See Cardelle de Hartmann, 2007, pp. 84-95.

19 See Jellouschek, I932, p. XXXX.

${ }^{20}$ See Tschacher, 2000, pp. I33-I73. 
pulus, which the Cistercian and novice master Caesarius of Heisterbach adapted to the relationship of monk (Monachus) and novice (Novicius) in his Dialogus miraculorum (ca. 1220). Nider transfers the monastic situation of the conversation in the Dialogus miraculorum to the sphere of university erudition. He supports his argumentation for a persistent presence of the miraculous by means of a wealth of personal experiences, which he puts into the voice of the Theologus. These experiences extend back to the author's childhood, and then primarily touch on the events surrounding his journeys in the service of the Council of Basel or monastic reform. Amongst other issues, Nider refers to conversations which he held in the Scottish Abbey in Vienna with the abbot and with a monk by the name of Benedict concerning his career as a necromancer and imposter. Martin of Leibitz was able to connect up to these experiences from the Scottish Abbey, in order to develop his own life history. The Formicarius, irrespective of the new quantity of autobiographical "moments", adheres to the dialogue framework of the Dialogus miraculorum, by following a structure according to theological principles. The individual chapters illustrate each of the characteristics of the ants, which are then assigned to the "spiritual" virtues of humans. Martin of Leibitz departs from this tradition in that he organises the first three of the eight chapters of the Senatorium according to the stages of life of man: childhood (pueritia), youth (adolescentia) and manhood (virilis aetas). This compartmentalization gives the work a biographical framework and roughly corresponds to the three stages which Cicero sets out, before old age (senectus), in his Cato major $(20,76)$. Petrarch's Epistola posteritati begins with a character sketch which is based on three stages of life and moral development, since childhood (adolescentia) deceived him, youth (iuventa) corrupted him, while age (senectus), however, improved him. Martin connects the three ages of life with the three institutions of school, university and monastery. The stage of life of "manhood" retains its purifying function through the entry into a monastery, the conversio, which appears as the focus of the third chapter. Each chapter proceeds from the knowledge of the elderly man, knowledge which comprises that which one has experienced, that which one has learned, and that which one has heard. The youth in the question-and-answer dialogue, just as the Piger in the textual prototype, is an inquisitive cue-giver who challenges his partner by agreement or contradiction.

The conventional teacher figure of the Monachus or of the Theologus requires the setting of monastery or university, where the reader could locate the conversation and its audience without narrative introduction. Just as with the Dialogus miraculorum, the Malogranatum and the Formicarius, a much greater indirect impact of the Senatorium is implied, which is today difficult to grasp. 
The dialogue intermingles the events in his life with numerous anecdotes. Martin describes the road to scholarship as beset with hurdles, and begins with his difficult journey to school during the cold, dark winters in the Carpathian Mountains. Once, in the moonlight, the child saw a large horse from which he fled, because he did not know anything about the remedial power of the sign of the cross as a means of warding off the apparition. It is edifying stories such as these which are related to the true and false miraculous signs in the Formicarius. Theologists of the "Vienna School" regarded these anecdotes as potential elements of a pastoral-theological reclamation in vernacular tracts and sermons, in order to prevent fallacious religious orientations amongst the laity. ${ }^{21}$ Monastic reform belonged to a religious-moral reform movement which ultimately should include all of society. The elderly man, for example, warns the youth not to draw hasty conclusions regarding the metaphysical significance of a wailing voice which was heard above the rooftops of his parental home before it burned down. Within the Senatorium, thoroughly critical statements regarding the growth of cults of relics and saints are found, yet there are also anti-Hussitic and anti-Semitic remarks. The childhood history serves to anchor the elderly man firmly in lay religiosity, when he describes the unswerving Passion devotion of his father: "saepe Deus simplici rustico dat devotionem" (Pez, I725, col. 627). In the characterisation of the father, Martin hints at his own simple origins, origins which did not hinder an ambitious career. The separation of monastery and nobility constituted one of the most important goals, and at the same time greatest problems, of the Melk Reform, since noble abbots often maintained secular lifestyles after their election. ${ }^{22}$ Visitors assessed, in the monasteries which they visited, whether influential families had favoured the election of particular candidates. In a similar fashion as with Wolfgang of Steyr and Johannes Schlitpacher, the protocol of the visitation journey of I45I/52 also constituted the essential core of the self-description by Martin of Leibitz. Martin interwove the detailed report of his journey into the Senatorium as a discrete chapter (4), and thereby denounced openly the massive opposition of the local nobility (nobiles) to a stricter lifestyle in the monasteries. For example, he attributes to them the following words regarding the enclosure of nuns: "Nos volumus in faciem resistere illis Monachis, qui volunt recludere filias nostras" (Pez, I725, col. 642). In contrast to the noble pride of rank, the author presents

${ }^{21}$ See Tschacher, 2000, pp. 216-218; also Cardelle de Hartmann, 2007, p. 82.

${ }^{22}$ See Niederkorn, 1994, p. 84. 
himself as an autodidact and social climber who, in spite of all external adversity has attained the pinnacle of the social hierarchy by means of prayer and studiousness: "qui frequens fuit in orationibus, diligens in studio", he lauded a school companion (Pez, I725, col. 627). The autobiography invokes the universal validity of the Benedictine virtues, in order to demonstrate the new power of education within late Medieval feudal society.

4. THE CONTEMPORARY FRAMEWORK: MONASTIC INQUISITIO AND ACADEMIC CORRESPONDENCE

The inquisitio of the monastery Visitors forced the individual monks into self-reflection regarding their suitability for a life of seclusion. Martin of Leibitz simulates in the third chapter of his Senatorium an interrogation of such a kind, which is then taken over by the youth and which proceeds from the decision to enter a monastery. The older man describes his path to inner contemplation as a rational process, in which emotions only played a subordinate role. He records his initial disdain for the transience of the world and his veneration for the learned church fathers, from Saint Jerome to Bonaventure. To the worldly impediments or "excuses" against entering a monastery, namely the guardianship of his nephews or fear of his employers, follows a series of divine foreordinations such as the discovery of a lost nephew and the death of the father of his master. The youth is not satisfied with this intellectualizing account of the conversio, and instead wishes to know why the Senex left Sacro Speco? The question becomes an accusation: "Quare non permanisti in loco tam sancto? Forte timuisti rigorem?" (Pez, I725, col. 635). The provocation offered by the youth is situated within the thematic framework of the Melk Interrogatorium (I450), a catalogue of questions by means of which the Visitors examined the inner attitude of the monks towards poverty, obedience, or abstinence. Specifically, Martin of Leibitz touches on the area of problems of the Horae lectionum et operis manuum. The elderly man answered that everything was bearable for him, even service in the kitchen, washing up dishes, or scooping water; nevertheless, the convention of staying awake after Matins was so unbearable to him that he fell asleep even on the most uncomfortable of surfaces and was incapable of doing anything afterwards. In contrast to Petrarch's Secretum, the dialogue does not have the character of a private examen conscientiae, that goes through the peccata hominis interioris before the confession. Martin publicly acknowledges transgressions against the rules and discipline, as with the peccata hominis exterioris, which should be laid bare communally, and 
punished. ${ }^{23}$ The text suggests the enclosed atmosphere of a chapter hall, in which the monk knows to designate the physical weakness of tiredness with the spiritual temptations of his own pusillanimitas. Martin of Leibitz emphasises that, in contrast to Sacro Speco, in the Melk Reform abbeys it was permitted to sleep until Prime, which encouraged him to return to Vienna. His decision was based on the consuetudines, the permitted local adaptations of the Regula Benedicti. In the context of the explanations regarding the advantages of the Vienna Scottish Abbey, the youth asks, "Quid tibi cum Medicis, cum sis Monachus" (Pez, I725, col. 650). The fact that a monk attends to medicine does not appear self-evident, based on this question. The elderly man refers to authorities such as the Old Testament (Sir. 38,4) and Augustine, in order to overcome any doubts concerning the legitimacy of medicine. In particular, he invokes the ethical obligation of the monk to care for his fellow brethren during illness and times of uncertainty. Just as he does for medicine, Martin declares jurisprudence as necessary for the abbey, for example when questions of excommunication arose: "debet enim homo facere quod in se est primo, \& postea residuum committere Domino Deo" (Pez, 1725, col. 650). These statements regarding the importance of secular knowledge are aimed at a dissociation with regard to the northern and western German congregational order of Bursfelde (I440), with which Melk was in rivalry, yet nevertheless continued to carry out negotiations of union. The negotiations failed because, amongst other things, Bursfelde only permitted study based on purely sacred interests and also rejected a non-theological lectio privata of the monks. ${ }^{24}$ The less strict regulations of the Melk Reform, on the other hand, permitted Martin of Leibitz to cite, in addition to the patristics, also dicta by Ovid or Seneca in his theological-ascetic Trialogus de militia christiana (ca. I455). The Benedictine reform of the $15^{\text {th }}$ century was divided in important questions of the consuetudines, whence latitude arose with regard to the "self" at the margins of the norms. In the Senatorium, Martin of Leibitz demands for everyone the freedom to select, from the offerings of ways of life within the order, that which most suited their own individual character.

The author of the Senatorium exploited his authority as a narrator by means of his capacity to be able to interpret correctly in retrospect things heard and experienced: "experientias in Virili statu exploratas". The wise man's competence in interpretation is part of his experientia and relates to academic knowledge, from

${ }^{23}$ See Niederkorn, I994, pp. I49-I56.

${ }^{24}$ See Niederkorn, 1994, pp. 33, I6I. 
which he deduces his insight into divine will. He describes, for example, a false, unconsecrated bishop from the period of his youth, in order to reassure the anxious young man of the validity of the sacrament from the hands of a sinful priest: "Bonum ergo, dicunt aliqui Doctores, est, quod homo adoret Sacramentum sub conditione, si omnia facta sunt quae requiruntur ad consecrationem Sacramenti." (Pez, I725, col. 63I) Martin considers his life as a meaningful, well-rounded life cycle, since, with the resignation of the abbacy, his duty within the hierarchy of the order was broadly fulfilled. At the time of the reform, such a resignation was clearly viewed through the stigma of guilt, as particularly non-conformist office holders voluntarily stepped down or were forced to do so by the Visitors on the strength of papal authority. The Senatorium fends off this suspicion, in that it portrays the elderly man as a self-sacrificing protagonist who is even ready to endanger his life for the ideas of the reforms. In Chapter 6, Martin of Leibitz addresses the question of the abdication of prelates. The youth appears to be uncertain whether such a step is legitimate at all; the aged man clears up his doubt. He connects the resignation with valid grounds, and then mentions individual popes, bishops and abbots as examples of such a step, for example Benedict's student Maurus of Subiaco, who is believed to have spent his last days in a lonely cell. When the old man addresses problems dealing with canon law, then the self-expression links up with the expert opinions or evaluations which the professors and graduates of Vienna University had expressed in detailed questions dealing with vegetarianism, the service of mass, or regarding the education of young monks. ${ }^{25}$ The reform turned the university into a decisive authority regarding questions of monastic life, so that monks from the Scottish Abbey regularly participated in disputations and shared their content with the abbey. For the university, the abbeys in turn were a central authority in the dissemination of guidelines regarding belief. This mutual dependency facilitated a dovetailing of personnel between college and monastery. It is apparent from the preserved correspondence that the legal scholar Martin of Leibitz was one of the academic experts who was consulted by monasteries. The act of writing down questions and answers in letters found its continuation in the autobiographical dialogue. As with the entrance into the monastery, in the case of resignation the general curiosity of the youth escalates into a personal attack. Namely, he would like to know what the elderly man thinks of abbots who, after their abdication, reserved money and then would spend their wealth at their own discretion. The elderly man immediately relates this accusation to himself, since

${ }^{25}$ See Niederkorn, 1994, pp. 5I-54. 
he, without his requesting it, also received the offer of such a livelihood: "cum sine mea instantia oblata fuit michi talis provisio" (Pez, 1725, col. 650). The payment of a "pension" constituted a necessary incentive for the Visitors, in order to induce insubordinate abbots to resign voluntarily. On this basis alone, the financing for old age did not correspond to the self-image of a prelate, who voluntarily subjects the administration of his duties to a final visitation: the elderly man spoke with learned, morally upright men, who preferred an alimony in the form of provisions of food instead of payments, in order to avoid the appearance of having assets. The expert Martin of Leibitz uses the learned men, who remain anonymous, as a pretext, since he is delivering a judgement in his own case. The resigned abbot holds up his own literary accomplishments against the suspicion of idleness, which, citing the Regula Benedicti, he views as a tool against that vice: "Assumpsi etiam hunc laborem ad vitandum otium \& taedium." (Pez, I725, col. 625). The writer interprets the retirement as part of the work of reform, which continues on a new level in the altered radius of activity of old age.

According to the chapters, the Senatorium can be roughly divided into an autobiographical section (Chaps. I-4) and a generally historical-encyclopaedic section (Chaps. 5-8). If the first three chapters follow the human stages of life, so the following chapters segue from the Cusanian Visitation into local and regional history, but return again to the autobiographical starting point, and finally to the question of the resignation. With Chapter 7, Martin follows the Dialogi of Gregory the Great; like him, he wishes to honour the local saints. The eighth and final chapter diverges from the previous ones in that the chain of argumentation is not disturbed by detailed questions posed by the youth, and instead a monologue by the elderly man is presented. Within this, the aged man reveals God's creation plan in the spiritual significance of the number 7 , from the seven canonical hours, through the planets and ages of the world, up to the seven heavenly gratifications. The Confessiones of Saint Augustine also led into a consideration of the seven days of creation. Martin of Leibitz describes his development, according to the Augustinian model, as an ascent into increasingly larger organisations, from the parental home, via the monastic order, local history and local saints, up to the creation. The numerological line of argument clearly follows Jean Gerson's symbolic interpretation of the number 7 , for example in La mendicité spirituelle. ${ }^{26}$ The chancellor of the Sorbonne was closely linked to the theologists of the

${ }^{26}$ See Pascoe, 1973, p. 2I. Johan Huizinga in "The Waning of the Middle Ages" (Chap. 15) pointed out the significance of the number 7 in Gerson. 
"Vienna School" after his stay in Melk and Vienna in I4I8/I4I9, and he shared their catechetical concerns. He belonged to the most frequently quoted authors of the monastic reform: the catalogue of the Melk library of $\mathrm{I} 483$ lists his writings in 43 manuscripts. ${ }^{27}$ In the concluding monologue of the Senatorium, Gerson substitutes the Formicarius as model for its content. The youth breaks off the dialogue in Chapter 7 with the explanation that the elderly man is daily becoming iller and weaker, could only complete the mass with difficulty the day before, and while praying the litany fell into mental confusion. This subplot makes the following variation of the number 7 into part of a preparation for death or ars moriendi, which ties the salvation of the ill person to a humble doxology. In the final chapter the meaning of the biography is fulfilled, as according to the words of the youth, the previous seven chapters correspond to the systematic of the number 7 , so that the dialogue subjugates the socialisation of the elderly man to the same cosmological principles of creation.

\section{CONCLUSION}

The concluding academic monologue legitimates the Benedictine reform movement as an element of a divine plan, which is accomplished in the curriculum vitae of an individual person. Monastic reform required the absorption of the individual into the collective community, so that the description of one's own life demanded a form of fictionalization which concealed the impetus of the earthly "memoria". The Senatorium provides a glimpse into a heretofore unobserved form of the autobiographical dialogue in the late Middle Ages, which integrated structures of self-representation from the Dialogi up to the Formicarius into the concept of the human stages of life. The Dialogi of Gregory the Great are recognisable in the Senatorium as a template which is filled with contemporary possibilities for monastic self-thematization in interviews, visitiation reports, academic letters or didactic dialogues. All of these elements have to do with recognised forms of conversation and writing of the reform, so that the boundaries of the "ego" also resulted from them, boundaries which cannot be measured in Petrarch's Secretum and its literary foundations. The Visitations made an ongoing self-representation, self-observation and self-justification into an internalised gesture of writing and formed the core element of Martin's memoirs of his life.

See Hobbins, 2009, p. 209. 
The Visitations targeted a thematic catalogue of questions which could be posed regarding the lifestyle of individuals and which defined their position in the community. In this respect, during the reform movement the dialogue constituted an appropriate form to approach one's own life.

Since the term autobiography represents a creation of the period around I80o, the autobiographical dialogue of the pre-modern era also cannot be described as a cohesive literary genre. A broad assessment of this particular form of life-writing in its various facets and forms during the late Middle Ages is still awaited. The observations proposed here are limited to evidence of intertextual references in the Senatorium and have not taken into consideration its reception as autobiography and as dialogue. The transmitted manuscripts, in which the dialogue partners are written throughout with red instead of black ink, would for example deserve a closer investigation. The dramatic presentation stands out much more strongly than in the Baroque printing, which made a Dialogus Historicus out of the Dialogus and which lent the work the character of a memoir. In the manuscripts the Senatorium presents itself as an open, variable dialogue of the author about his past. The incomplete theological dialogue Quotlibetarium follows the retrospective conversation only in the Salzburg tradition, but not in the Melk one; this was intended as the redemption of a promise of the Senex and picks up again the thread of a discussion from Chapter 5. The repetition of the innovative constellation of figures of the Senex and Juvenis in this later work made the Senatorium into an autobiographical frame of reference for further intellectual accomplishments. The history of reception therefore must have begun with Martin of Leibitz himself, who in the Quotlibetarium alludes to the provisional end of the dialogical self-construction with a quotation from the Psalms: "incolatus meus prolongatus est" ${ }^{28}$

BIBLIOGRAPHY

Achitz, W., 2012-2013: Deutsches Literatur-Lexikon. Das Mittelalter, vol. I-3, Berlin - Boston.

Amelung, J. S., 20II: "Tracing Lives. The Spanish Inquisition and the Act of Autobiography”, in A. Baggerman, R. Dekker, M. Mascuch (eds.), Controlling

${ }^{28}$ Jellouschek, 1932, p. 185 (prologue). 
Time and Shaping the Self. Developments in Autobiographical Writing since the Sixteenth Century, Leiden - Boston, pp. 33-48.

Burke, P., 1997: "Representations of the Self from Petrarch to Descartes", in R. Porter (ed.), Rewriting the Self. Histories from the Renaissance to the Present, London - New York, pp. 17-28.

Cardelle de Hartmann, C., 2007: Lateinische Dialoge I200-I400. Literaturhistorische Studie und Repertorium, Leiden - Boston.

Fleming, J. V., 20I4: "Medieval European Autobiography", in M. DiBattista (ed.), The Cambridge Companion to Autobiography, New York, pp. 35-48.

Frank, I. W. - Worstbrock, F. J., I987: “Martin von Leibitz”, in K. Ruh (ed.), Die deutsche Literatur des Mittelalters, Verfasserlexikon, vol. 6, Berlin - New York, col. I53-I57.

Hermans, H. J. M. - Hermans-Konopka, A., 20Io: Dialogical Self Theory. Positioning and Counter-Positioning in a Globalizing Society, Cambridge.

Hobbins, D., 2009: Authorship and Publicity before Print. Jean Gerson and the Transformation of Late Medieval Learning, Philadelphia.

Jellouschek, K. J., I932: Martini de Leibitz Trialogi ascetici, Passau.

Knapp, E., 2009: “Thomas Hoccleve”, in L. Scanlon (ed.), The Cambridge Companion to Medieval English literature II00-I500, Cambridge, pp. I9I-205.

Lee, A., 20I2: Petrarch and St. Augustine. Classical Scholarship, Christian Theology and the Origins of the Renaissance in Italy, Leiden.

Martin, D.D., 1992: Fifteenth Century Carthusian Reform. The World of Nicholas $\operatorname{Kempf}$, Leiden.

McLaughlin, J., 2004: "Biography and Autobiography in the Italian Renaissance”, in P. France, W. St. Clair (ed.), Mapping Lives: The Uses of Biography, Oxford, pp. 37-65.

Mixson, J. D., 2009: Poverty's Proprietors. Ownership and Mortal Sin at the Origins of the Observant Movement, Leiden - Boston.

Niederkorn-Bruck, M., 1994: Die Melker Reform im Spiegel der Visitationen, Wien.

Pascoe, L. B., 1973: Jean Gerson. Principles of Church Reform, Leiden.

Pez, H., I725: Scriptores Rerum Austriacarum, vol. 2, Leipzig.

Redlich, V., I93I: Tegernsee und die deutsche Geistesgeschichte im Is. Jahrhundert, München.

Rubinstein, J., 2005: "Biography and autobiography in the Middle Ages", in N. Partner (ed.), Writing Medieval History, London, pp. 22-4I.

Schmitt, J.-C., 1998: Ghosts in the Middle Ages. The Living and the Dead in Medieval Society, Chicago - London. 
Shank, M. H., 1987: "A Female University Student in Late Medieval Kraków", in Signs, I2, pp. 373-380.

Siegmund, A., 1980: "Martin de Leibitz (ou de Vienne)", in Dictionnaire de Spiritualité, vol. Io, Paris, col. 683-684.

Stock, B., 200I: After Augustine. The Meditative Reader and the Text, Philadelphia.

Summers, J., 2004: Late-Medieval Prison Writing and the Politics of Autobiography, Oxford.

Tschacher, W., 2000: Der Formicarius des Johannes Nider von 1437/38. Studien zu den Anfängen der europäischen Hexenverfolgungen im Spätmittelalter, Aachen. Wallnig, Th., et al., 2010-2015: Die gelehrte Korrespondenz der Brüder Pez. Text, Regesten, Kommentare, vol. I-2, Wien.

Zimmermann, T. C. Price, 1971: "Confession and Autobiography in the early Renaissance”, in A. Molho - J. A. Tedeschi (eds.), Renaissance. Studies in Honor of Hans Baron, Firenze, pp. II9-I40. 